\title{
Survey of Salty and Sweet Whey Composition from Various Cheese Plants in Wisconsin
}

\author{
K. M. Blaschek, W. L. Wendorff, ${ }^{1}$ and S. A. Rankin \\ Department of Food Science, University of Wisconsin, Madison 53706
}

\begin{abstract}
Salty whey is currently underutilized in the dairy industry because of its high salt content and increased processing and disposal costs. Salty whey accounts for 2 to $5 \%$ of the total whey generated during Cheddar and other dry-salted cheese manufacture. Because relatively little information is available on salty whey, this study was conducted to determine the range of compositional components in salty whey from commercial cheese plants. Gross compositional differences in percent protein, salt, solids, and fat between sweet whey and salty whey from various dry-salted cheeses from 8 commercial plants were determined. Differences between individual whey protein compositions were determined using sodium dodecyl sulfate-PAGE. Average total solids, fat, and salt content were significantly greater in the salty whey compared with the corresponding sweet whey. True protein was reduced in salty whey although great variability existed among samples. Individual whey proteins identified included lactoferrin (Lf), BSA, immunoglobulin G, $\beta$-lactoglobulin, and $\alpha$-lactalbumin. Salty whey showed an increase in Lf content and a decrease in $\alpha$-lactalbumin and $\beta$-lactoglobulin content when compared with sweet whey. Salty whey may be a source of Lf, potentially increasing its value to whey processors. However, the compositional assessments showed that commercial salty whey is a highly variable waste stream.
\end{abstract}

Key words: salty whey, lactoferrin, whey protein

\section{INTRODUCTION}

Whey proteins present in whey are valuable functional ingredients with a variety of applications. Some proteins recovered from salty whey may also be of value. Of particular interest is a glycoprotein from the transferrin family, lactoferrin (Lf). A preliminary study suggested that salty and press whey from Cheddar cheese

Received November 17, 2006.

Accepted December 19, 2006.

${ }^{1}$ Corresponding author: wlwendor@wisc.edu may contain a substantial increase in Lf concentration compared with sweet whey (Rao and Wendorff, 2003). If salty whey is a significant source of Lf compared with sweet whey, it could add value to this currently underutilized whey stream. However, little information is available on salty whey gross composition or protein profiles.

When salty whey is drained from the cheese vat postcurd salting, it has a $\mathrm{pH} \sim 5.2$ (Kapoor and Metzger, 2004). The typical salt content of salty whey from Cheddar and Colby cheeses ranges from approximately 0.7 to $1.7 M(4.1$ to $10 \%)$. The typical mean values previously reported for percentage salt, fat, and moisture of salty whey are 8.71, 1.69, and 82.2\%, respectively (Kapoor and Metzger, 2004). Percentage protein has been reported to be around 1\% in salty whey (Zall and ElSamragy, 1988). However, the whey protein profiles of salty whey are currently unknown. This study surveyed commercial sweet and the corresponding salty whey samples from 8 cheese plants in Wisconsin to determine the range of compositional differences including whey protein profiles.

Specifically, the purposes of this study were to 1) compare gross composition including true protein, salt, fat, and moisture content of various sweet and salty wheys from dry-salted Cheddar, Mozzarella, and Colby cheeses, and 2) compare individual whey protein profiles of sweet and salty whey.

\section{MATERIALS AND METHODS}

\section{Whey Collection}

Dry-salted Cheddar, Mozzarella, and Colby cheese sweet and salty whey samples were collected through the months of May 2005 to January 2006 from 8 Wisconsin cheese plants at the time of manufacture. Mozzarella salty whey was recovered from partial direct-salting of the curd prior to the pasta filata process. Samples were immediately cooled to refrigeration temperature $\left(4^{\circ} \mathrm{C}\right)$ and shipped frozen to the University of WisconsinMadison Food Science Department, and stored frozen at $-18^{\circ} \mathrm{C}$ until analyzed. Prior to analysis, samples were 
Table 1. Gross composition of commercial Cheddar cheese sweet and salty whey samples ${ }^{1}$

\begin{tabular}{|c|c|c|c|c|}
\hline \multirow[b]{2}{*}{ Component $^{2}$} & \multicolumn{2}{|c|}{ Sweet whey } & \multicolumn{2}{|c|}{ Salty whey } \\
\hline & Average & Range & Average & Range \\
\hline Moisture, \% & $93.4 \pm 0.4^{\mathrm{a}}$ & 91.6 to 96.5 & $87.6 \pm 5.8^{b}$ & 75.9 to 93.8 \\
\hline Total solids, \% & $6.6 \pm 1.3^{\mathrm{b}}$ & 3.5 to 8.4 & $12.4 \pm 5.9^{\mathrm{a}}$ & 6.1 to 24.1 \\
\hline Fat, $\%$ & $0.2 \pm 0.1^{\mathrm{b}}$ & 0.1 to 0.4 & $0.6 \pm 0.3^{\mathrm{a}}$ & 0.2 to 1.1 \\
\hline True protein, $\%$ & $0.8 \pm 0.2^{\mathrm{a}}$ & 0.4 to 1.0 & $0.6 \pm 0.2^{b}$ & 0.3 to 1.0 \\
\hline Salt, \% & $0.2 \pm 0.1^{\mathrm{b}}$ & 0.1 to 0.4 & $6.9 \pm 5.2^{\mathrm{a}}$ & 2.6 to 18.9 \\
\hline
\end{tabular}

thawed at $7^{\circ} \mathrm{C}$ overnight and then passed through cheesecloth to remove cheese particles.

Whey samples obtained during the Cheddar cheese manufacturing process were obtained from Babcock Hall Dairy Plant in Madison, Wisconsin. The Cheddar cheese manufacturing process followed the procedure outlined by Price et al. (1971).

\section{Compositional Analysis}

Gross composition of samples was determined using the following standard methods (AOAC, 2005). Total nitrogen was determined by Kjeldahl (method 991.20). Nonprotein nitrogen was determined with Kjeldahl analysis after selective precipitation by the addition of TCA solution (method 991.21). True protein was determined by difference. Percentage moisture was determined using a moisture analyzer (method 985.14, Omnimark uwave Moisture Analyzer Omnimark Instrument Corporation, Tempe, AZ). Percentage of total solids was determined as 100 - percentage moisture. Percentage of salt was determined using a chloride analyzer (M926 Chloride Meter, Nelson-Jameson Inc., Marshfield, WI). Percentage of fat was determined by modified Mojonnier ether extraction (method 989.05). Samples were analyzed in duplicate.

\section{Electrophoresis}

Individual whey proteins of the salty and sweet whey samples were analyzed using SDS-PAGE (Bio-Rad Criterion Cell, Hercules, CA) based on the discontinuous Laemmli method (Laemmli, 1970). Whey samples were centrifuged for $20 \mathrm{~min}$ at $3,500 \times g$ to remove fat. Salty whey samples were dialyzed against distilled water for $4 \mathrm{~h}$ in dialysis tubes with a molecular weight cutoff of 3,500 Da (Fisher Scientific, Hampton, NH). This was done to remove salt to the level present in sweet whey and prevent precipitation during sample denaturation. Sweet and salty whey samples were centrifuged again at $4,500 \times g$ for $60 \mathrm{~min}$ in a centrifugal filter (Centricon YM-3 Millipore, Billerica, MA) to remove solutes with a molecular weight below 3,500 Da. Namely, the filter removes salt and lactose, which can interfere with electrophoresis. A 4 to $20 \%$ precast gradient Tris- $\mathrm{HCl}$ gel with 18 wells was used (Criterion, Bio-Rad). Standard curves for IgG, $\beta$-LG, $\alpha$-LA, Lf, and BSA were used to identify individual whey proteins in the samples seen in the gels (Sigma Chemical Co., St. Louis, MO). The protein standards created were loaded (5 to $25 \mu \mathrm{g} / 10$ $\mu \mathrm{L})$ at levels seen in sweet whey. Samples were then heated to $95^{\circ} \mathrm{C}$ for $5 \mathrm{~min}$ with Laemmli sample buffer (Bio-Rad) and $100 \mathrm{mM}$ (wt/vol) dithiothreitol (Bio-Rad) to denature the proteins. Samples were loaded and the

Table 2. Gross composition of commercial Colby cheese sweet and salty whey samples ${ }^{1}$

\begin{tabular}{|c|c|c|c|c|}
\hline \multirow[b]{2}{*}{ Component $^{2}$} & \multicolumn{2}{|c|}{ Sweet whey } & \multicolumn{2}{|c|}{ Salty whey } \\
\hline & Average & Range & Average & Range \\
\hline Moisture, \% & $94.2 \pm 0.9^{\mathrm{a}}$ & 92.8 to 95.0 & $90.6 \pm 1.1^{\mathrm{b}}$ & 89.8 to 92.9 \\
\hline Total solids, \% & $5.8 \pm 0.9^{b}$ & 5.0 to 7.1 & $9.8 \pm 0.5^{\mathrm{a}}$ & 8.8 to 10.2 \\
\hline Fat, $\%$ & $0.5 \pm 0.2^{\mathrm{b}}$ & 0.2 to 0.8 & $0.8 \pm 0.4^{\mathrm{a}}$ & 0.4 to 1.2 \\
\hline True protein, $\%$ & $0.6 \pm 0.2$ & 0.5 to 0.9 & $0.7 \pm 0.2$ & 0.5 to 0.9 \\
\hline Salt, \% & $0.1 \pm 0.0^{b}$ & 0.1 to 0.1 & $4.0 \pm 0.6^{\mathrm{a}}$ & 3.1 to 4.8 \\
\hline
\end{tabular}

${ }^{\mathrm{a}, \mathrm{b}}$ Means within the same row without a common superscript differ $(P<0.05)$.

${ }^{1}$ Mean values \pm SD for 4 lots of each type of whey, analyzed in duplicate $(n=4)$.

${ }^{2}$ Values reported as mean percentage (wt/wt) of total whey composition. 
Table 3. Gross composition of commercial Mozzarella cheese sweet and salty whey samples ${ }^{1}$

\begin{tabular}{|c|c|c|c|c|}
\hline \multirow[b]{2}{*}{ Component $^{2}$} & \multicolumn{2}{|c|}{ Sweet whey } & \multicolumn{2}{|c|}{ Salty whey } \\
\hline & Average & Range & Average & Range \\
\hline Moisture, \% & $91.5 \pm 1.3$ & 90.1 to 93.0 & $91.4 \pm 2.0$ & 88.7 to 93.9 \\
\hline Total solids, \% & $8.5 \pm 1.3$ & 7.0 to 9.9 & $8.6 \pm 2.0$ & 6.1 to 11.3 \\
\hline Fat, \% & $0.4 \pm 0.2$ & 0.2 to 0.6 & $0.6 \pm 0.4$ & 0.2 to 1.3 \\
\hline True protein, \% & $1.0 \pm 0.1^{\mathrm{a}}$ & 0.8 to 1.1 & $0.7 \pm 0.2^{\mathrm{b}}$ & 0.5 to 1.0 \\
\hline Salt, \% & $0.2 \pm 0.1^{\mathrm{b}}$ & 0.1 to 0.3 & $2.5 \pm 2.3^{\mathrm{a}}$ & 0.3 to 5.0 \\
\hline
\end{tabular}

gels were run at $200 \mathrm{~V}$ until the band was seen $1 \mathrm{~cm}$ from the bottom of the gel. The gels were stained in Coomassie blue staining solution (Bio-Rad) for about 1 $\mathrm{h}$ and destained in $10 \%$ acetic acid (vol/vol), $40 \%$ metha$\mathrm{nol}(\mathrm{vol} / \mathrm{vol}$ ), and $50 \%$ water (vol/vol) for about $4 \mathrm{~h}$ with several changes.

Individual protein bands were scanned using a densitometer (GS-710 Imaging Densitometer, Bio-Rad) and quantified using software (Quantity One, Bio-Rad). The optical densities of each protein sample band were compared with known standards. Each band was quantified based on the relative percentage of the total whey protein.

\section{Whey Protein Solubility}

In an attempt to explain the differences in whey protein profiles in salty whey, the solubilities of Lf, $\beta$-LG, and $\alpha$-LA in salt solutions were determined using model systems similar to those of de Wit and van Kessel (1996). The conditions chosen for the model systems were comparable with commercial salty whey. Salt solutions containing $0,1.5,3$, and $6 \% \mathrm{NaCl}$ were created using phosphate buffer at $\mathrm{pH}$ 5.2. One percent protein was added to the respective salt solutions. Stirring, centrifuging, and filtering steps were followed according to de Wit and van Kessel (1996). The nitrogen content of all samples with and without $\mathrm{NaCl}$ was determined.

\section{Statistical Analysis}

All data were analyzed using 1-way ANOVA with statistical software (R 2.1.1, The R Development Core Team, Auckland, New Zealand) with a significance level at $P<0.05$.

\section{RESULTS AND DISCUSSION}

\section{Compositional Analysis}

The mean values for the gross composition of Cheddar, Colby, and Mozzarella cheese salty whey and sweet whey are shown in Tables 1, 2, and 3. The solids content of Cheddar and Colby salty whey was significantly higher than that of the respective sweet whey. The difference in solids appears to be primarily due to the salt content. Mozzarella cheese salty whey solids content was not significantly different from sweet whey. Moisture content was significantly higher in Cheddar and Colby cheese sweet whey vs. salty whey, which relates to the solids content. The value for moisture in salty whey was comparable with reported values by Kapoor and Metzger (2004). The moisture content of the Mozzarella salty whey samples was not significantly

Table 4. Distribution of whey proteins in commercial Cheddar cheese sweet and salty whey samples ${ }^{1}$

\begin{tabular}{|c|c|c|c|c|}
\hline \multirow{2}{*}{$\begin{array}{l}\text { Whey } \\
\text { protein }^{1}\end{array}$} & \multicolumn{2}{|c|}{ Sweet whey } & \multicolumn{2}{|c|}{ Salty whey } \\
\hline & Average & Range & Average & Range \\
\hline Lactoferrin & $1.0 \pm 0.7^{\mathrm{b}}$ & 0.3 to 2.4 & $15.0 \pm 4.1^{\mathrm{a}}$ & 7.5 to 19.6 \\
\hline BSA & $2.9 \pm 0.6^{\mathrm{a}}$ & 2.1 to 4.0 & $1.7 \pm 0.6^{\mathrm{b}}$ & 0.8 to 3.3 \\
\hline IgG & $4.5 \pm 1.2^{\mathrm{a}}$ & 2.9 to 7.1 & $3.0 \pm 0.7^{\mathrm{b}}$ & 2.0 to 4.4 \\
\hline$\beta-\mathrm{LG}$ & $57.9 \pm 2.5^{\mathrm{a}}$ & 53.8 to 64.8 & $50.4 \pm 3.7^{\mathrm{b}}$ & 44.5 to 59.2 \\
\hline$\alpha-\mathrm{LA}$ & $24.6 \pm 1.3^{\mathrm{a}}$ & 22.4 to 26.4 & $20.0 \pm 1.8^{\mathrm{b}}$ & 17.0 to 24.2 \\
\hline Other & $9.2 \pm 3.0^{\mathrm{b}}$ & 3.6 to 14.8 & $9.8 \pm 3.5^{\mathrm{a}}$ & 3.9 to 15.8 \\
\hline
\end{tabular}

${ }^{\mathrm{a}, \mathrm{b}}$ Means within the same row without a common superscript differ $(P<0.05)$.

${ }^{1}$ Mean values \pm SD for 12 lots of each type of whey, analyzed in duplicate $(n=12)$.

${ }^{2}$ Values reported as mean percentage (wt/wt) of total whey protein. 
Table 5. Distribution of whey proteins in commercial Colby cheese sweet and salty whey samples ${ }^{1}$

\begin{tabular}{|c|c|c|c|c|}
\hline \multirow{2}{*}{$\begin{array}{l}\text { Whey } \\
\text { protein }^{2}\end{array}$} & \multicolumn{2}{|c|}{ Sweet whey } & \multicolumn{2}{|c|}{ Salty whey } \\
\hline & Average & Range & Average & Range \\
\hline Lactoferrin & $2.2 \pm 1.0^{\mathrm{b}}$ & 0.9 to 3.4 & $14.5 \pm 8.6^{\mathrm{a}}$ & 6.2 to 23.9 \\
\hline BSA & $2.4 \pm 0.4^{\mathrm{a}}$ & 1.9 to 2.9 & $2.0 \pm 0.3^{\mathrm{b}}$ & 1.7 to 2.5 \\
\hline $\operatorname{IgG}$ & $3.6 \pm 0.8$ & 2.3 to 4.5 & $2.7 \pm 0.7$ & 2.0 to 3.7 \\
\hline$\beta-\mathrm{LG}$ & $60.4 \pm 1.4^{\mathrm{a}}$ & 58.5 to 62.5 & $53.3 \pm 4.6^{\mathrm{b}}$ & 47.0 to 58.1 \\
\hline$\alpha$-LA & $24.1 \pm 0.6$ & 23.2 to 25.3 & $21.4 \pm 3.9$ & 17.0 to 26.1 \\
\hline Other & $7.4 \pm 1.1$ & 5.5 to 8.7 & $6.1 \pm 1.0$ & 4.7 to 7.2 \\
\hline
\end{tabular}

${ }^{\mathrm{a}, \mathrm{b}}$ Means within the same row without a common superscript $\operatorname{differ}(P<0.05)$.

${ }^{1}$ Mean values \pm SD for 4 lots of each type of whey, analyzed in duplicate $(n=4)$.

${ }^{2}$ Values reported as mean percentage (wt/wt) of total whey protein.

different from sweet whey. The fat content of Cheddar cheese salty whey was significantly higher than that of sweet whey. The fat content of Colby and Mozzarella cheese salty whey was not significantly different than the corresponding sweet whey. Due to further agitation of the Cheddar curd postsalting, more of the fat was released into the salty whey vs. sweet whey. Percentage fat for salty whey from all 3 cheese types was lower than the average value of $1.69 \%$ reported by Kapoor and Metzger (2004). The protein content of Cheddar and Mozzarella cheese sweet whey was significantly higher vs. salty whey. The protein content of Colby cheese salty whey was not significantly different from sweet whey. Protein content of salty whey reported by Zall and El Samragy (1988) was comparable at around $1 \%$. The salt content was significantly greater in the salty whey of all 3 cheese varieties compared with sweet whey because of the curd salting done just prior to when salty whey was expelled. Salt content of salty whey reported by Kapoor and Metzger (2004) was higher at $8.71 \%$. The $\mathrm{pH}$ for the salty whey samples ranged from 5.2 to 5.4, which was similar to Kapoor and Metzger (2004).

\section{Whey Protein Profiles}

Tables 4, 5, and 6 show the relative proportions of the individual whey proteins analyzed from Cheddar,
Colby, and Mozzarella salty and sweet whey samples. Differences seen between salty and sweet whey profiles may be due to the influence of increased ionic strength of salty whey. Because the environment is different for these 2 types of whey as far as $\mathrm{pH}$ and ionic strength, these factors could influence protein solubility.

The ionic strength of the whey can influence protein solubility. Proteins can be salted-in or salted-out due to the salt concentration of the solvent. Salting-in occurs when the solubility of a protein is increased, whereas salting-out occurs when a protein precipitates due to decreased solubility. The large salt content differences between salty and sweet whey could be a factor in the differences seen in their whey protein profiles. The $\mathrm{pH}$ also affects protein solubility. If the $\mathrm{pH}$ of the solvent is above or below the protein's isoelectric point, the protein will generally be more soluble. However, a $\mathrm{pH}$ near a protein's isoelectric point will cause charge neutralization and possible precipitation of the protein.

Salty whey showed a significant $(P<0.05)$ increase in Lf content for all 3 cheese types. There was also a significant $(P<0.05)$ decrease in $\alpha$-LA and $\beta$-LG content in Cheddar cheese salty whey when compared with sweet whey. This trend was similar to the preliminary results found by Rao and Wendorff (2003). However, there were some differences from these preliminary results. Bovine serum albumin, IgG, and the other minor

Table 6. Distribution of whey proteins in commercial Mozzarella cheese sweet and salty whey samples ${ }^{1}$

\begin{tabular}{|c|c|c|c|c|}
\hline \multirow{2}{*}{$\begin{array}{l}\text { Whey } \\
\text { protein }{ }^{2}\end{array}$} & \multicolumn{2}{|c|}{ Sweet whey } & \multicolumn{2}{|c|}{ Salty whey } \\
\hline & Average & Range & Average & Range \\
\hline Lactoferrin & $1.9 \pm 1.5^{\mathrm{b}}$ & 0.8 to 4.8 & $8.9 \pm 5.3^{\mathrm{a}}$ & 3.6 to 15.4 \\
\hline BSA & $2.2 \pm 0.7$ & 1.0 to 3.0 & $2.2 \pm 0.8$ & 1.0 to 3.5 \\
\hline IgG & $3.8 \pm 2.2$ & 1.4 to 6.6 & $4.3 \pm 1.8$ & 2.0 to 6.5 \\
\hline$\beta-\mathrm{LG}$ & $59.3 \pm 3.7^{\mathrm{a}}$ & 51.0 to 61.9 & $53.0 \pm 5.0^{\mathrm{b}}$ & 47.1 to 58.8 \\
\hline$\alpha$-LA & $25.4 \pm 1.7^{\mathrm{a}}$ & 21.7 to 26.7 & $21.9 \pm 4.5^{\mathrm{b}}$ & 14.8 to 25.8 \\
\hline Other & $7.4 \pm 3.3$ & 3.9 to 14.9 & $9.6 \pm 3.6$ & 6.1 to 15.2 \\
\hline
\end{tabular}

\footnotetext{
${ }^{\mathrm{a}, \mathrm{b}}$ Means within the same row without a common superscript $\operatorname{differ}(P<0.05)$.

${ }^{1}$ Mean values \pm SD for 4 lots of each type of whey, analyzed in duplicate $(n=4)$. Salty whey was recovered from presalting operations in Mozzarella manufacture.

${ }^{2}$ Values reported as mean percentage (wt/wt) of total whey protein.
} 
Table 7. Effect of $\mathrm{pH}$ on distribution of whey proteins during Cheddar cheese manufacture ${ }^{1}$

\begin{tabular}{|c|c|c|c|c|}
\hline \multirow{2}{*}{$\begin{array}{l}\text { Whey } \\
\text { protein }\end{array}$} & \multicolumn{4}{|c|}{$\mathrm{pH}$ of whey } \\
\hline & 6.4 & 6.3 & 5.8 & 5.4 \\
\hline Lactoferrin & $0.9 \pm 0.4^{\mathrm{d}}$ & $1.5 \pm 0.2^{\mathrm{c}}$ & $6.6 \pm 0.2^{\mathrm{b}}$ & $15.3 \pm 0.7^{\mathrm{a}}$ \\
\hline BSA & $3.9 \pm 1.1$ & $4.7 \pm 1.2$ & $3.1 \pm 0.4$ & $3.3 \pm 0.6$ \\
\hline $\operatorname{IgG}$ & $8.6 \pm 2.2$ & $9.4 \pm 1.8$ & $6.8 \pm 0.2$ & $6.5 \pm 0.7$ \\
\hline$\beta-\mathrm{LG}$ & $57.4 \pm 3.3^{\mathrm{a}}$ & $56.2 \pm 2.6^{\mathrm{a}}$ & $55.9 \pm 0.7^{\mathrm{a}}$ & $51.1 \pm 0.2^{\mathrm{b}}$ \\
\hline$\alpha-\mathrm{LA}$ & $29.2 \pm 0.5^{\mathrm{a}}$ & $28.2 \pm 0.5^{\mathrm{a}}$ & $27.6 \pm 0.1^{\mathrm{a}}$ & $23.8 \pm 0.4^{\mathrm{b}}$ \\
\hline
\end{tabular}

whey proteins considered decreased significantly in Cheddar cheese salty whey from sweet whey, but not in Colby or Mozzarella cheese salty whey. This could be due to the fact that with the proportional increase in percent Lf concentrations in salty whey, the percentage of the remaining whey proteins out of total protein decreases.

\section{Whey Protein Solubility}

The results from model systems simulating salty whey conditions showed the solubilities of $\mathrm{Lf}, \alpha-\mathrm{LA}$, and $\beta$-LG were not affected by salt concentration. There was no salting in or increase in solubility for Lf. There was also no decrease in solubility or salting out precipitation seen for $\alpha$-LA or $\beta$-LG.

To further investigate the origin of increased Lf in salty whey, samples of whey were collected at 6 different times during the Cheddar cheese manufacturing process at one of the cheese plants. Samples included cheese milk, sweet whey after the curd was cut, drained sweet whey, whey after cheddaring, whey postcurd milling, and salty whey. Table 7 shows the distribution of whey proteins during Cheddar cheese manufacture. The Lf concentrations were significantly higher in whey during cheddaring and milling than in sweet whey drained at $\mathrm{pH}$ 6.3. As Lf concentrations increased, concentrations of $\beta$-LG and $\alpha$-LA were proportionately decreased. Previous studies (Mehra et al., 1988; Lampreave et al., 1990) have shown that Lf can bind with casein or other whey proteins. Because Lf is a basic protein, it has been shown to interact with acidic proteins such as casein through electrostatic binding (Ena et al., 1990). With the decrease in milk pH during cheesemaking, the net negative charge of individual casein molecules and micelles is reduced (Uricanu et al., 2004). The stabilization of casein micelles is reduced and the protein's net charge becomes neutral. This neutralization may weaken the Lf casein binding, thereby releasing Lf into the whey. Ionic strength may also play a role in increased Lf in salty whey. After salting the curd, Lf represented 19.9\% of the total protein in salty whey. Further studies are needed to determine the potential association and dissociation of Lf with casein as affected by $\mathrm{pH}$ and ionic strength.

\section{CONCLUSIONS}

The composition of commercial salty whey from Wisconsin cheese plants was a highly variable waste stream. Compared with sweet whey, however, there were some noted differences. Because a significant increase of Lf was seen, salty whey could serve as a potential source of high value minor whey proteins. The decrease in $\mathrm{pH}$ during the cheesemaking process seems to play a critical role in the increased Lf in salty whey. The increased salt content in salty whey could also affect Lf solubility. Further examination of the change in casein micelles during cheesemaking is needed to understand the potential release of Lf into whey streams for maximum recovery of Lf from the cheesemaking process.

\section{ACKNOWLEDGMENTS}

A very special thanks to the various cheese plants throughout the state that donated whey samples for this survey. A special thanks to Gary Grossen, master cheesemaker at the Babcock Hall Dairy Plant, for providing milk and whey samples for the cheesemaking studies. Thanks also to Dattatreya Banavara for technical assistance in this study. This research was supported in part by the College of Agricultural and Life Sciences, University of Wisconsin, Madison.

\section{REFERENCES}

Association of Official Analytical Chemists. 2005. Official Methods of Analysis. 18th ed. AOAC Int., Gaithersburg, MD. 
de Wit, J. N., and T. van Kessel. 1996. Effects of ionic strength on the solubility of whey protein products. A colloid chemical approach. Food Hydrocoll. 10:143-149.

Ena, J. M., H. Castillo, L. Sánchez, and M. Calvo. 1990. Isolation of human lactoferrin by affinity chromatography using insolubilized bovine $\beta$-lactoglobulin. J. Chromatogr. 525:442-446.

Kapoor, R., and L. E. Metzger. 2004. Evaluation of salt whey as an ingredient in processed cheese. J. Dairy Sci. 87:1143-1150.

Laemmli, U. K. 1970. Cleavage of structural proteins during the assembly of the head of bacteriophage T4. Nature 227:680-685.

Lampreave, F., A. Piñeiro, J. H. Brock, H. Castillo, L. Sánchez, and M. Calvo. 1990. Interaction of bovine lactoferrin with other proteins of milk whey. Int. J. Biol. Macromol. 12:2-5.
Mehra, R., M. McEnroe, and W. Donnelly. 1988. Quantification of lactoferrin in bovine milk fractions. Biochem. Soc. Trans. 16:215-216

Price, W. V., H. E. Calbert, and N. F. Olson. 1971. Making Cheddar cheese from pasteurized milk. Bull. 464, Res. Div., Coll. Agric. Life Sci., Univ. Wisconsin, Madison.

Rao, R. D., and W. L. Wendorff. 2003. Compositional differences between whey, salty whey, and press whey from commercial manufacture of Cheddar cheese. J. Dairy Sci. 86(Suppl. 1):365. (Abstr.)

Uricanu, V. I., M. H. G. Duits, and J. Mellema. 2004. Hierarchical networks of casein proteins: An elasticity study based on atomic force microscopy. Langmuir 20:5079-5090.

Zall, R. R., and Y. A. El-Samragy. 1988. Utilization of salt whey for the production of yeast protein. Cult. Dairy Prod. J. 23:28-31. 